\title{
Fodder Halophytes for Saline Lands of Kyzylkum Desert
}

\author{
Lola S. Ortiqova \\ Djizak State Pedagogical Institute, Djizak, Uzbekistan \\ Email: ozodbek88@bk.ru
}

How to cite this paper: Ortiqova, L.S. (2019) Fodder Halophytes for Saline Lands of Kyzylkum Desert. American Journal of Plant Sciences, 10, 1517-1526.

https://doi.org/10.4236/ajps.2019.109107

Received: July 29, 2019

Accepted: September 7, 2019

Published: September 10, 2019

Copyright $\odot 2019$ by author(s) and Scientific Research Publishing Inc. This work is licensed under the Creative Commons Attribution International License (CC BY 4.0).

http://creativecommons.org/licenses/by/4.0/

\begin{abstract}
The article is devoted to the economic and biological characteristics of promising desert semi-shrub halophytes (Kochia prostrate, Salsola orientalis, Ceratoides ewersmaniana, Halothamhus subaphyllus, Camphorosma lessingii) to improve saline lands of the Kyzylkum desert.
\end{abstract}

\section{Keywords}

Kyzylkum, Desert, Pastures, Saline Lands, Karakul

\section{Introduction}

The Kyzylkum desert, often known geographically Botanical references as the Kyzylkum district [1] [2] [3], is a large footprint and economic importance of the region of Karakul breeding in Central Asia.

The Kyzylkum desert occupies a large part of the flat territory of Uzbekistan and southern Kazakhstan with altitudes of 100 - 300 (700) m near the sea and is located between the rivers Amudarya, Syrdarya, lower and middle reaches of Zaravshan.

Kyzylkum at the current level of development of productive forces in agricultural production is the largest pasture region of Karakul within Uzbekistan, Kazakhstan and the Republic of Karakalpakstan. It is dominated by pastures year-round use, accounting for almost $80 \%$ of the total area of the district [2].

This huge desert area is diverse in geological and geomorphologic against powerful sand formations (ridges, hills, dunes), relict mountain areas (Bukantau, Aristantau, Aktau, Kazakhtau, Djetimtau, Sangruntau, Kokchatau, etc.), plains, pits of depression (Ayakagitma, Karakata, Mingbulak, Beshbulak, etc.).

In geomorphology of Kyzylkum there are also alluvial low plains, and the re- 
lief of the Aral part was formed under the influence of the Aral Sea-along the Eastern shore is characterized by the deposition of loose and fixed Sands.

The sands of Kyzylkum are the product of centuries-old destruction of sediments that compose the plateau itself. They have a characteristic reddish color (the Uzbek term "Kyzylkum" literally means "red sand"), which owes its name to the entire Kyzylkum desert.

Believe it is appropriate to briefly elaborate on the General characteristics Ayakagitma and Karatin troughs-the area of the present study.

Ayakagitma and Karatin basin is located on the administrative boundaries of Gijduvan, Shafirkan, Karmana districts of Bukhara and Navoi regions of Uzbekistan. Common footprint is only one Ayakagitma basin of about $20 \mathrm{~km}^{2}$ [4].

The geomorphological structure of the Ayakagitma depression is quite complex and variegated. It is a saucer-like surface, in some years, sometimes accumulated a small amount of precipitation. This is salt marsh of Bashagitma; there are other small areas of wet salt marshes, often populated by representatives of most supplies of salt-resistant halophytes, or no vegetation.

The outskirt of this relatively large basin is a terraced formation and wide gentle slopes with uneven terrain. The banks of the depression are often precipitous; they are quite clearly visible outputs of various tertiary rocks-green and red clay, sandstones, marls. In some places, alluvial and proluvial formations are well traced. Separate arrays of cavities, especially near the count, Akmurt, Yavshan-Tepe marked area of aeolian sandy sediment in the form of bumps and ridges.

The soil cover Ayakagitma basin is quite diverse. From 6 types (grey-brown, desert-sandy, takir, meadow, bog, and salt marshes), 9 subtypes and 31 kinds of soils are characteristic of arid areas in Ayakagitma depression found in almost all of these types and options.

On elevated areas gray-brown and desert-sandy soils of different mechanical composition prevail; in depressions and moist places with close groundwatersaline soils, meadow, meadow-marsh soils [5].

Similar or nearly similar structure of geomorphology is inherent in Karakatin basin. Research Institute of Karakul and desert ecology (Uzbekistan) began to systematically deal with the study of feed halophytes since 1982 under the scientific guidance of Professor Z. Sh. Shamsutdinova [6] [7] [8] [9] [10].

The main purpose of the research of this institution, as a scientific staff of Karakul, was and is the development of scientific and technological foundations of phytomelioration of pastures including saline lands of Uzbekistan.

To achieve this goal, the research program consisted of the following main tasks:

Collection and creation of the gene pool of fodder halophytes; testing and evaluation of fodder halophytes in saline desert conditions; study of palatability and nutritional value of promising halophyte species; development of agrotechnical methods of cultivation of fodder halophytes in the conditions of culture; 
identify the specifics of the water regime of promising fodder halophytes in terms of culture.

Field studies conducted on pastures latitudinal economy "Madaniyat" of Kanimex district of Navoi region. The experimental site is located $150 \mathrm{~km}$ North-West of the city of Navoi at an altitude of 130 m.n.u.m., the farm specializes in the production of Karakul products.

The natural conditions of the research area are sharply continental and arid. The annual amount of atmospheric precipitation for a long period, averages 120 $\mathrm{mm}$, ranging from 38.2 to $264.5 \mathrm{~mm}$. the main period of precipitation-autumn, winter and earlier spring (XI-IV). The average annual temperature is $14.8^{\circ} \mathrm{C}$; the average monthly July $32.4^{\circ} \mathrm{C}$, absolutely maximum $-45^{\circ} \mathrm{C}-48.3^{\circ} \mathrm{C}$; minimum (January, December) $-15^{\circ} \mathrm{C}-19^{\circ} \mathrm{C}$.

The soils of the experimental field (state farm "Madaniyat", array "Kizil kesek") are quite saline from the surface (Table 1); at a depth of $28-62 \mathrm{~cm}$ the salt content is significantly reduced; even lower $(62-100 \mathrm{~cm})$ the content of the dense residue is $1.2 \%$ (Table 1 ).

Among 87 samples comprised of 9 Botanical families, one and perennial halophytes in a culture of the Kyzylkum desert in such important biological parameters as survival, the dynamics of annual growth and amount of biomass on prospects objects in the feed, biomeliorative relations were perennial shrubs (Kohia prostrate, Salsola orientalis, Ceratoides eversmaniana, Halonamnus sufaphyllis), etc.

More detailed results of the research are reflected in the press [11]-[18].

The main purpose of this report is the economic and biological characteristics of promising phytomeliorants from the number of semi-shrub halophytes used to improve the saline pastures of Kyzylkum.

Below you will find the botanical characteristics of some plants.

Table 1. The composition of the aqueous extract of the soil of experimental plot, Kanimex region, "state farm Madaniyat", array "Kizil kesek", Mg/eq. Analytical chemist-Lee. P.M.

\begin{tabular}{|c|c|c|c|c|c|c|c|c|c|}
\hline \multirow{2}{*}{$\begin{array}{c}\text { Horizon, } \\
\mathrm{cm}\end{array}$} & \multirow{2}{*}{$\begin{array}{c}\text { Dense } \\
\text { residue, \% }\end{array}$} & \multicolumn{4}{|c|}{ Anions } & \multicolumn{4}{|c|}{ Cations } \\
\hline & & $\mathrm{CO}^{3}$ & $\mathrm{HCO}_{3}$ & $\mathrm{Cl}$ & $\mathrm{SO}_{4}^{2}$ & $\mathrm{Ca}$ & $\mathrm{Mg}$ & $\mathrm{Na}$ & K \\
\hline \multirow{2}{*}{$0-2$} & \multirow{2}{*}{13.62} & $\underline{0.0012}$ & $\underline{0.04 .09}$ & $\underline{0.1932}$ & $\underline{89.09}$ & $\underline{0.0360}$ & $\underline{0.1403}$ & $\underline{40.600}$ & $\underline{0.0380}$ \\
\hline & & 0.04 & 0.72 & 5.448 & 18.54 & 1.79 & 11.53 & 17.72 & 0.972 \\
\hline \multirow{2}{*}{$2-28$} & \multirow{2}{*}{9.23} & \multirow{2}{*}{ - } & $\underline{0.0171}$ & $\underline{0.4781}$ & $\underline{5.9669}$ & $\underline{0.0500}$ & $\underline{0.1757}$ & $\underline{2.7750}$ & $\underline{0.0153}$ \\
\hline & & & 0.28 & 13.482 & 12.42 & 2.49 & 14.45 & 12.06 & 0.39 \\
\hline \multirow{2}{*}{$28-62$} & \multirow{2}{*}{6.78} & \multirow{2}{*}{$\begin{array}{l}- \\
-\end{array}$} & $\underline{0.0145}$ & $\underline{0.2072}$ & $\underline{0.4013}$ & $\underline{0.0300}$ & $\underline{0.0683}$ & $\underline{0.1635}$ & $\underline{0.008}$ \\
\hline & & & 0.23 & 5.84 & 8.35 & 1.40 & 5.61 & 7.09 & 0.22 \\
\hline \multirow{2}{*}{$62-100$} & \multirow{2}{*}{1.24} & \multirow[b]{2}{*}{ 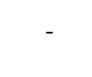 } & $\underline{0.0136}$ & $\underline{0.1673}$ & $\underline{0.7029}$ & $\underline{0.9380}$ & $\underline{0.0964}$ & $\underline{0.2220}$ & $\underline{0.0037}$ \\
\hline & & & 0.22 & 4.71 & 14.63 & 1.89 & 7.92 & 9.65 & 0.09 \\
\hline \multirow{2}{*}{$\begin{array}{c}\text { Subsoil } \\
\text { water }\end{array}$} & \multirow{2}{*}{12.4} & $\underline{0.0288}$ & $\underline{0.0329}$ & $\underline{0.3885}$ & $\underline{0.4057}$ & $\underline{0.0420}$ & $\underline{0.0372}$ & $\underline{0.3182}$ & $\underline{0.0747}$ \\
\hline & & 0.96 & 0.54 & 10.0 & 8.45 & 2.08 & 3.65 & 13.8 & 1.91 \\
\hline
\end{tabular}




\section{Cochia prostrata (L.) Schrad.}

Botanical characteristics. Xerophilous shrub: $30-75 \mathrm{~cm}$, from the family Chenopodiaceae. There are three ecotypes: sandy, rocky, clay.

Sand (Cochia) is characterized by ascending branches, covered with hairs, with filiform-linear, fibrous leaves. Inflorescence paniculate, with flowers collected in clumps.

Seeds: round-oval, smooth, brownish, $1.2-2.0 \mathrm{~mm}$ long and 1.0 and $1.5 \mathrm{~mm}$ wide, in the center on both sides dented. Weight of 1000 seeds: $0.9-1.2 \mathrm{~g}$.

The root system of ecotypes of Izena well developed both horizontally and in depth of the soil. In the foothill semi-desert penetrates to a depth of $6.0 \mathrm{~m}$, sandy desert-4.5 - $5.2 \mathrm{~m}$, gypsum desert-3.5 m [19].

Stony (Cochia) has a greenish color and a weak descent of shoots and leaves. Its typical growing conditions-crushed and stony soils of foothills and mountains; gray earth of different mechanical composition. It is a valuable plant for the creation of hayfields and pasture agrophytocenoses in the desert and semi-desert.

Clay (Cochia) istands out light yellow, sometimes reddening shoots with a slight omission. It grows on clay loamy soils, in the mountains of Pamir-Alai, Tien Shan and on saline soils of the Northern subzone of deserts and semi-deserts of the arid zone.

The ecotypes of Cochia vegetate in conditions of culture of the Kyzylkum desert from early spring till late autumn (Figure 1). In late may-June form buds; bloom in late July-August. Seeds ripen in October-early November. Throughout the growing season are in a green state. The length of the growing season-220 260 days.

Area and ecology: Grows on sandy and sandy loam soils in Kyzylkum, Muyunkum, middle and lower Volga region and other areas of sandy, rocky deserts.

The nutritional value of the Cochia is not lower than the nutritional value of oats (Larin 1951). In the budding phase contains $14.3 \%-15.6 \%$ crude protein, $2.7 \%-3.28 \%$ fat, $39.5 \%$ - $43.5 \%$ nitrogen-free extractives and $26.5 \%-30.8 \%$ fiber.

The leaves contain a large amount of protein 14.7 , little $(4.7-39.6 \mathrm{mg} / \mathrm{kg})$ of carotene and lignin $(10.7 \%-18.5 \%)$ from trace elements a lot of zinc-17.0 K/kg and amino acids (lysine, leucine, isoleucine) [8].

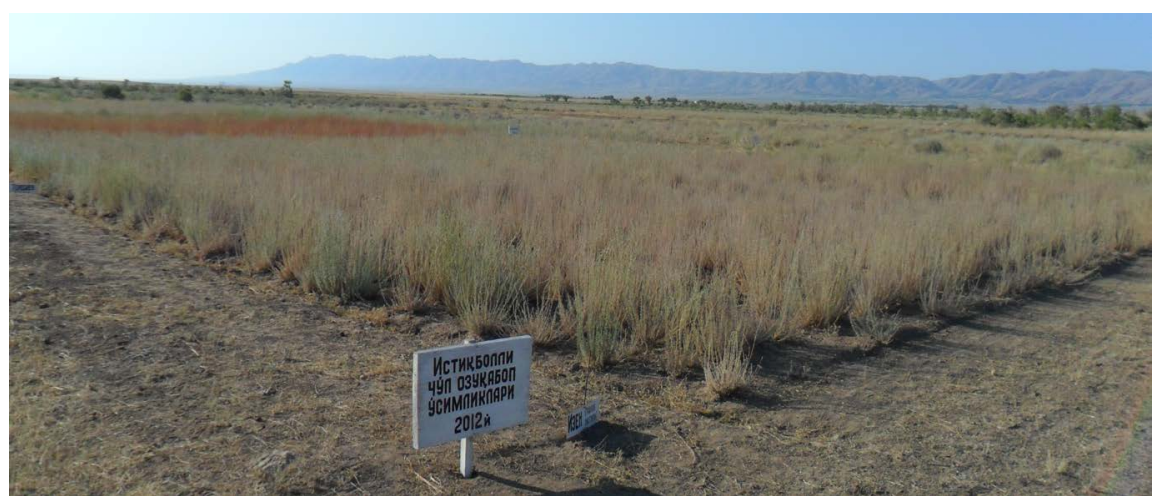

Figure 1. Crops of Cochia prostrata (state farm in Uzbekistan). 
Depending on season of use in $100 \mathrm{~kg}$ of feed contains Asenavage 83.5 - 45.1 food unit and $5.6 \mathrm{~kg}$ of digestible protein [20].

Pasture value. It is perfectly eaten by sheep, goats and camels in all seasons of the year.

Cochia-valuable grazing, fattening plant in a culture of the Kyzylkum desert harvest his forage is $14-16 \mathrm{~kg} / \mathrm{ha}$. Due to its valuable feed advantages, high yield, salt resistance, izen stands out among other types of desert shrubs.

In Research Institute of Karakul and desert ecology and zoned 5 varieties ("Karnabchul”, "Desert”, "Sahra”, "Otavniy”, "Nurota”) of Cochia [21].

\section{Ceratoides ewersmanninana (Stschegl. et. Losinsk.) Botsch. et. Ikonn.}

Botanical characteristics: semi-shrub of the family of Chenopodiaceae from 40 to $120 \mathrm{~cm}$ in height.

The root system of the universal type penetrates to a depth of $5-6 \mathrm{~m}$. The Leaves are all-cut, flat, alternate with short petioles, oblong-oval, strongly lowered. Shoots light green, straight at the base (Figure 2).

Phenology: blooms in July-August, bears fruit in September-October.

Area and ecology. It grows in the Aral-Caspian, Balkhash, Kyzylkum, near the Syrdarya, Tien-Shan, Pamir, Afghanistan and Western Mongolia. Inhabits sand, finely earthy-rubbly, stony-rubbly and loess slopes of the mountains and the lowlands, on dry roam rivers and sais.

Nutritional value: green shoots and leaves during flowering contain $16 \%$ crude protein, $2.7 \%$ fat, $3.4 \%$ crude fiber. $100 \mathrm{~kg}$ of dry food contains $9.1 \mathrm{~kg}$ of digestible protein and $37.9 \mathrm{~kg}$ of fodder food.

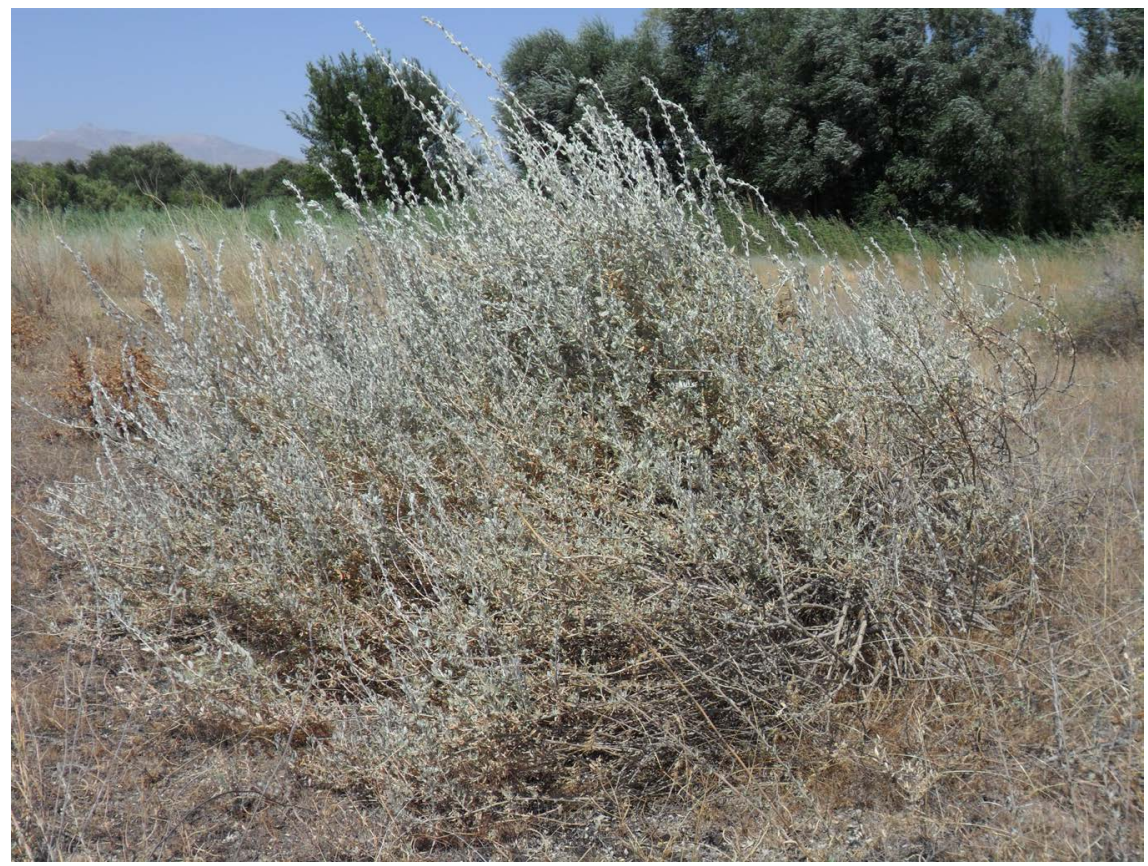

Figure 2. Ceratoides ewersmanninana in the phase of fruiting (2014 year). 
Pasture value. Good food for cattle, horses, sheep. Well eaten annual shoots and leaves, more likely in the autumn-winter season. The yield of teresken in the culture of Kyzylkum $-10-12 \mathrm{C} / \mathrm{ha}$. In culture in the first year of life reaches a height of $35-40 \mathrm{~cm}$, in the second and subsequent years-50-70 cm.

Teresken has a high drought resistance, longevity, good yields and adaptability to the harsh conditions of the Kyzylkum desert.

It is a valuable object for improvement of pastures in saline desert.

In Research Institute of Karakul and desert ecology display a variety of teresken "Tulkin".

\section{Salsola orientalis. G. Gmel. (S. Rigida Pall.)}

Botanical characteristics: Perennial, polymorphic haloxerophyte height up to 85 , usually $40-55 \mathrm{~cm}$ of the family Chenopodiaceae (Figure 3 ).

Annual shoots of gray-green color, straight or ascending, with linear, hairy leaves. The leaves are succulent, alternate, awl-shaped, drooping. Root system of universal type [22].

Seeds with pericarp, yellowish-dark brown. The seed peel is two-layer with an intermediate cuticle (12 - 26 microns). The embryo is spirally twisted. Distinguish gypsophilous, halophilic ekofarma [23].

The growth of keyreuk begins in March-April, blooms in June-August, bears fruit in October-November. Terminates the growing season after autumn frosts.

Area and ecology. Distributed in Central Asia, the Caspian coast of the Caucasus, Iran, Afghanistan and China. The most saturated areas of its area are the Aral Karakum, Kyzylkum, Ustyurt.

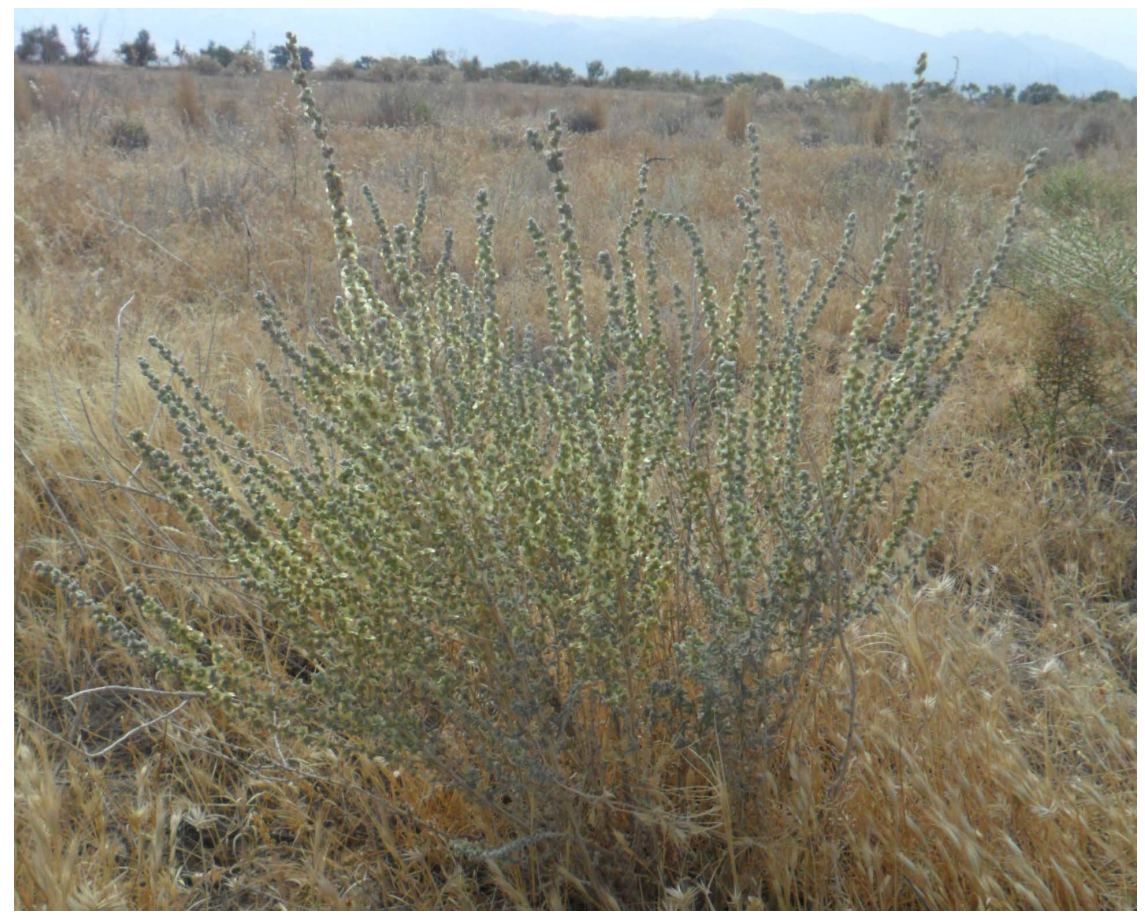

Figure 3. Blooming bush of Salsola orientalis. 
It grows on gray soils, gray-brown soils, takyrs, on low-power Sands; prefers a more dense soil and is rarely found on highly moist and plump saline soils. In plant communities with the participation of keyreuk shrubs are $7 \%-15 \%$, semi-shrubs-18 - 30\%, annual and perennial herbs-12\%-60\%.

Nutritional value: in the phase of regrowth (Kyzylkum) contains $16.9 \%$ protein, fiber-24.8\%, ash $-18.2 \%, \mathrm{BEV}-36.5 \%$. Rich in minerals: $1.35 \%-2.23 \%$ calcium $0.12 \%-0.31 \%$, phosphorus, sulfur $-0.64 \%-1.42 \%$, potassium- $2.2 \%$ $2.8 \%$ and $3.2 \%-5.2 \%$ sodium.

In $100 \mathrm{~kg}$ of feed in the spring contains 64.4 feed. Units summer-45.4, autumn-38.0, winter-29.6.

Amino acid composition is also diverse: the largest number of amino acids contained in the spring: $0.7 \mathrm{~g}$ arginine, $1.7 \mathrm{~g}$ aspartic acid; $2.4 \mathrm{~g}$ glutamic acid, $1.2 \mathrm{~g}$ glycine, $1.1 \mathrm{~g}$ alanine, $1.4 \mathrm{~g}$ valine, $0.25 \mathrm{~g}$ methionine, $1.4 \mathrm{~g}$ leucine, $0.5 \mathrm{~g}$ tyrosine, etc. [8].

The content of carotene in the vegetation phase is 85.4 ; vitamin C $-781 \mathrm{mg} / \mathrm{kg}$.

The grazing value: keyreuk eaten by sheep, goats, camels; often in the fall and winter. Eaten its parts are all above-ground vegetating parts of the current year in a green and dry state.

Feed productivity of keyreuk in various soil and soil conditions is $6.9-21.2$ C/ha of hay [12].

In Uzbekistan, launched and distributed a variety of keyreuk "the firstborn Karnab” (in Kazakhstan "Aydarli 1") [24].

Keyreuk is a valuable object for phytomelioration of arid pastures of saline, gypsum deserts of Central Asia [17].

\section{Halothamhus subaphyllus (C. A. Mey) Botsch.; (Salsola subaphylla (C. A. Mey); Allenia subaphylla (C. A. Mey); Aellen.}

Botanical characteristics: Shrub with a height of $50-120 \mathrm{~cm}$ of the family Chenopodiaceae. Escape is highly branched, light green. Leaves alternate, fleshy. The flowers are located in the axils of the bracts, single in spike inflorescences. Fruit: unopened nut, the size of the fruit is $12-20 \mathrm{~mm}$ (Figure 4).

Seeds: rounded, slightly concave $2-3.5 \mathrm{~mm}$. Embryo spiral, with a yellowish spine, and the two dark green cotyledons.

Phenology: Grows in March, blooms in may-July, and bears fruit in October-early November. The growing season ends in the autumn after frosts.

Area and ecology. Distributed on gravelly saline soils, gray-brown and gray soils, takyrs, on low-power Sands of the arid zone of Central Asia.

Nutritional value: leaves and twigs contain (\%) protein to $14 \%$; fiber content-23\%, ash substances-20\%. Its dry food in the budding phase contains crude protein $-24.7 \%$, fat $-2.7 \%, \mathrm{BEV}-36.9 \%$, and fiber $-18.3 \%$.

In $100 \mathrm{~kg}$ of dry food contains 52 summer, autumn-46 and winter 37 fodder food.

Pasture value: Valuable forage plant for sheep, goats, camels. Mainly eaten in 


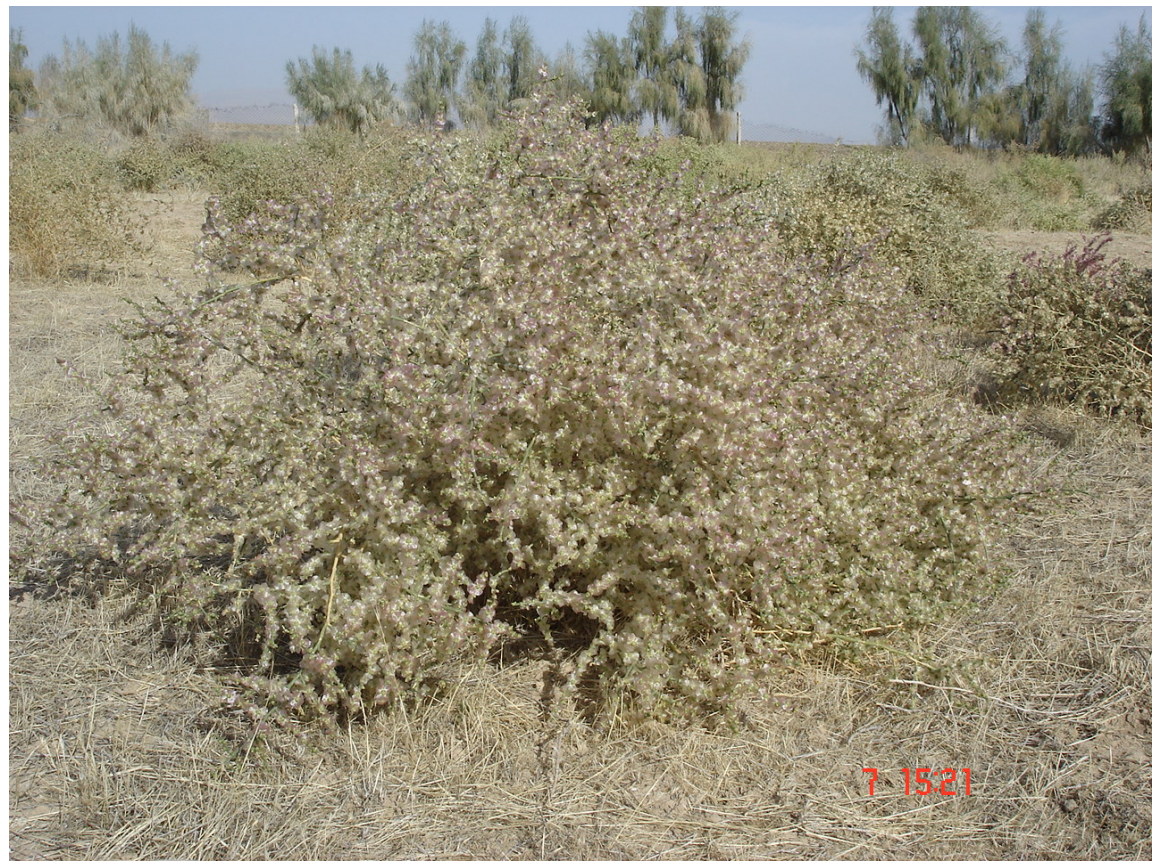

Figure 4. Halothamhus subaphyllus in the phase of fruiting (2014 years).

the autumn-winter season. Fodder productivity in nature $0.8-2.0$, in culture 8 $10 \mathrm{C} / \mathrm{ha}$ of air-dry mass. Seed productivity of $1.8-2.0 \mathrm{~kg} / \mathrm{ha}$.

Widely used in phytomeliorative arid pastures.

In Research Institute of Karakul and desert ecology (RIKDE) launched his sort "Jayhun".

\section{Camphorosma lessingii Litv.}

Botanical characteristics. Shrub of the family Chenopodiaceae with a height of $30-80 \mathrm{~cm}$. Morphologically from other semi-shrub salt pans is characterized in that its vegetative shoots often tightly pressed to the ground, and the generative shoots are covered with a whitish drooping.

Areal komforsmi-Central Asia, South-East of the European part of Russia, Western Siberia, Iran, Afghanistan, China, Mongolia.

It is more common in steppe, desert, and semi-desert zones [20].

Typical growing conditions are salt marshes, salt marshes, saline lands with close groundwater occurrence.

It is a drought-resistant, salt-tolerant, well-eaten by cattle plant for sheep, goats, and camels.

During the period of full fruiting camphor contains $14.4 \%$ protein, $2.2 \%$ fat, $35.2 \%$ fiber and $39.3 \% \mathrm{BEV}$.

$100 \mathrm{~kg}$ of dry camphor feed contains 44.5 feed in winter units and $9.3 \mathrm{~kg}$ of digestible protein [25].

Camphorosma is a plant capable of forming a deeply penetrating and powerfully developed root system.

Conclusions. Halophytes (there are more than 2000 of them in the world flo- 
ra, more than 700 species in the flora of Central Asia) are specific plants and are adapted to function normally, produce phytomass, bear fruit, and renew themselves in a saline growing environment.

The halophytes objects diversified household purposes, fodder, medicinal, food, oil-bearing plants, energy and biomeliorants.

Promising feed halophytes are characterized by valuable economic and biological properties.

\section{Conflicts of Interest}

The authors declare no conflicts of interest regarding the publication of this paper.

\section{References}

[1] Murzaev, E.M. (1973) Names of Asian Deserts. In: Problems of Desert Development, Institute of Deserts of Turkmenistan, Turkmenistan, 55-62.

[2] Sinkovsky, L.P. (1950) Artemisia is a Valuable Fodder Plant Winter Pastures Karakul Sheeps. In: The Message of The Taj, Volume 28.

[3] Korovin, E. (1961) P Vegetation of Central Asia and Southern Kazakhstan. 432 p.

[4] Granitov, I.I. (1950) vegetation Map of South-Western Kyzylkum. SAGA, Tashkent, $87 \mathrm{p}$.

[5] Butkov, N.A. and Nasyrov, M.Y. (1970) Soils of the South-Western Kyzylkum. Tashkent.

[6] Bekchanov, B. and Mahmudov, M.M. (2009) Galofites and Their Initial Results in the Kyzylkum Environment. In: Scientific Support of the Uzbek Agro-Industrial Complex (Materials of the Scientific Session) (na uzb.yazyka). Tashkent, Fan, 351-355.

[7] Shamsutdinov, Z., Savchenko, I.V. and Shamsutdinov, N.Z. (2000) The Halophytes of Russia: Their Environmental Assessment and Use. 399 p.

[8] Nikolaev, V.N., Gladysheva, L.E., Durdyev, N., et al. (1980) Chemical Composition, Nutritional Value and Biological Integrity Pasture Fodder of the Karakum Desert. Ashgabat.

[9] Ortikova, L.S. and Makhmudov, M.M. (2009) Halophytes-Valuable Objects to Phitomeliorative Arid Pastures. Proceedings of the International Scientific-Practical Conference "the Role of Young Scientists in the Development of Karakul, Shymkent, 88-89.

[10] Mahmudov, M.M. and Ortikova, L.S. (2009) Methods of Phytomelioration in the Pastures of Kyzylkum. Zooveterinary, 4, 43-45.

[11] Makhmudov, M.M. (1991) Keyreuk-Valuable Forage Plants in the Desert Zone of Uzbekistan. Samarkand, $63 \mathrm{p}$.

[12] Mahmudov, M.M. and Bekchanov, B. (2002) Galofites and Their Efficient Use-The Method of Desertification. In: Regional Problems of Natural Geography (Scientific Conferences) (uzb language). SamSU, Samarkand, 150-152.

[13] Mahmudov, M.M. and Bekchanov, B. (2005) Atriplex nitens an Important Phytomeliorant for the Saline Field in Kyzylkum. In: Problems of Desert Pasture Livestock Development (Materials of International Scientific Conference) (In uzb.). Samarkand, 189-193.

[14] Mahmudov, M.M., Bekchanov, B. and Ortiqova, L.S. (2009) Karakul an Important 
Nutritional Pasturage. Zooveterenaria, 6, 38-39.

[15] Mahmudov, M.M., Bekchanov, B. and Ortiva, H.P. (2009) Agronomic Basics Introduction Annual Forage Halophytes on Saline Soils in the Kyzyl Kum. In: Introduction of Plants-Problems and Prospects, Tashkent, 110-113.

[16] Mahmudov, M.M., Rabbimov, A., Bekchanov, B. and Ortikova, L.S. (2009) Experience Introduction to the Culture of Forage Halophytes in Saline Lands-The Desert of Uzbekistan. In: Eco-Friendly Technologies of Desert Pasture Livestock, Samarkand, 191-192.

[17] Nechaeva, N.T., Shamsutdinova, Z. and Mukhammedov, G.M. (1978) Improvement of Desert Pastures of Central Asia. Ashgabat, 62c.

[18] Ortikova, L.S. and Mahmudov, M.M. (2012) Introduction to the Culture of Fodder Halophytes-As a Way of Rational Use of Saline Lands of Kyzylkum Productive Camel Breeding, Karakul and Arid Forage Production in Kazakhstan. Materials of the international Scientific-Practical Conference, Shymkent, 256-258.

[19] Shamsutdinov, Z. (1975) Creation of Long-Term Pastures in the Arid Zone of Central Asia. Tashkent, $164 \mathrm{p}$.

[20] Larin, I.V., Aghababian, M.S., Rabotnov, T.A., et al. (1952) Fodder Plants of Hayfields and Pastures of the USSR. Volumes 1-3, $974 \mathrm{p}$.

[21] Rabbimov, A., Akimov, T., Khamraeva, G. and Margieva, B. (2013) IntroductionBreeding Work with a Desert Fodder Plants. In: Institutional Issues of Rational Use and Protection of Pastures, Materials of Republican Scientific-Practical Conference (In uzb). Tashkent.

[22] Makhmudov, M.M. (1968) Biological and Ecological Fundamentals in Management in Culture Keyreuk Salsosola Rigido Pall. In the South-Western Kyzylkum. Dushanbe, $21 \mathrm{p}$.

[23] Mamasaliev, I. (1970) Keyreuk Salsola orientalis S. J. Jmel and Its Variability in Uzbekistan. Tashkent, $20 \mathrm{p}$.

[24] Barangaziev, K.B. and Slabinskaya, A.I. (1975) The Study of Ecotypes of Keyreuk in Culture. Bulletin of Agricultural Science of Kazakhstan, 12.

[25] Razhabov, B. (1983) Biological and Ecological Features Camphorosma lessingii Litv. and the Experience of Its Introduction into Culture in Arid Regions of Uzbekistan. Dushanbe, $21 \mathrm{p}$. 